\title{
Effect of Sweet Potato Vine Planting Orientation on the Growth and Yield of Sweet Potato/Maize Intercropping System in Makurdi, Southern Guinea Savanna, Nigeria
}

\author{
Idoko, J.A ${ }^{\mathbf{1}}$, Akaazua, B. $\mathbf{W}^{\mathbf{2}}$. and Aduwele, A.T $\mathbf{T}^{\mathbf{3}}$
}

${ }^{1}$ Department of Crop Production, University of Agriculture, P.M.B.2373, Makurdi, Nigeria

\begin{abstract}
Two field experiments were carried out during the cropping seasons of 2016 and 2017 at the Teaching and Research Farm of the University of Agriculture, Makurdi, Benue State, Nigeria. The experiments sought to determine the effect of sweet potato vine orientation on growth and yield of sweet potato/maize intercropping system with a view to improve the productivity of maize/sweet potato intercropping in Makurdi. The experiment was a 2 x $2 \times 3$ split-split plot laid out in randomized complete block design with three replications. The main plot treatments were two cropping systems [sole cropping (sweet potato, maize), intercropping (sweet potato + maize)]. The sub plot treatments were made up of two maize varieties (pop.66SR/ACR.91 SUWAH 1-SR and M2: pool18R/AK94DMRESR-Y). The sub-sub plot treatments comprised of three (3) sweet potato vine orientations (incline, loop and horizontal). The result obtained from the experiment showed sole cropping gave higher cob length, number of seeds per cob, cob weight, grain yield and 100-seed weight of maize than intercropping in both years. In all years, pool18R/AK94DMRESR-Y produced higher yield and yield parameters of maize than pop.66SR/ACR.91 SUWAH 1-SR irrespective of the cropping system. In 2016 and 2017, horizontal vine orientation gave higher vine length, root diameter, root length, number of saleable roots per hectare and weight of saleable roots than all the other vine orientations. Intercropping with pop.66SR/ACR.91 SUWAH 1-SR gave higher growth and yield parameters than intercropping with pool18R/AK94DMRESR-Y. All intercrop combinations had LER figures above 1.0 and LEC values above 0.25 in both years. CR values of sweet potato were consistently higher than those of maize in all intercrop combinations in 2016 and 2017
\end{abstract}

Key words: Sweet potato, maize, variety, intercropping, sole cropping, vine orientation

\section{Introduction}

Maize (Zea mays L.) is an important staple food crop in Nigeria, containing about $72 \%$ starch, $10 \%$ protein, $4.8 \%$ oil, $8.5 \%$ fibre, $3.0 \%$ sugar and $1.7 \%$ ash (Chaudhary, 1983). It is adapted to various ecological zones of the country ranging from the rainforest in the South to the savanna zones of the Northern parts of the country[1].

Maize crop is a key source of food and livelihood for millions of people in many countries of the world. Its grain has great nutritional value and can be used as raw material for manufacturing many industrial products [2]. It is also a major component of livestock feed and it is palatable to poultry, cattle and pigs as it supplies them energy [3]. The grain, leaves, stalk, tassel and cob can be used to produce a large variety of food, non-food products [4].

Sweet potato (Ipomea batatas Lam) is an important food and industrial root crop in Nigeria. The crop is used as food for humans and domestic animals while in the industries, it is used to brew alcoholic beverages [5]. The roots are mainly starch and soluble carbohydrates, but the leaves and vines are high in amino acids, essential minerals and vitamins. Various parts of the crop have been reported to contain both organic and mineral nutrients including vitamins $\mathrm{A}$ and $\mathrm{C}$, zinc, potassium (K), sodium, manganese, calcium (Ca), magnesium $(\mathrm{Mg})$ and iron $(\mathrm{Fe})$ [6] [7].

Intercropping is a popular farming system among farmers in Nigeria especially the small scale farmers. This is majorly practiced to increase the productivity per unit of land and ensure economic utilization of land, labour and capital resources. 
Several researchers have worked on maize/sweet potato intercropping [8] [9]. However, different authors have recommended different vine orientations of sweet potato for optimum yield. [10] recommended vertical orientation, [11] recommended horizontal and loop vine orientations while [12] reported that higher yields will be obtained if sweet potato is planted at an angle or horizontally. This study was carried out toestablish the most suitable vine orientation for the Southern Guinea environment of Nigeria and to determine the effect of sweet potato vine orientation on the performance of sweet potato/maize intercrop.

\section{Material and Methods}

\section{Experimental Location}

A field experiment was carried out during the cropping seasons of 2015 and 2016 at the Teaching and Research Farm of the University of Agriculture, Makurdi [Latitude 07 ${ }^{\circ} 45^{\prime}-07^{\circ} 50^{\prime}$ $\mathrm{N}$, Longtitude $08^{\circ} \quad 45^{\prime}-08^{\circ} 50^{\prime} \mathrm{E}$, elevation 98 meters above sea level] in Benue State, located in Southern Guinea Savanna of Nigeria [13]. The experiment sought to determine the effect of sweet potato vine orientation on the performance of sweet potato/maize intercropping.

\section{Treatment and Experimental Design}

The experiment was a $2 \times 2 \times 3$ split-split plot laid out in randomized complete block design with three replications. The main plot treatments were two cropping systems [sole cropping (sweet potato, maize), intercropping (sweet potato + maize)].The sub plot treatments were made up of two maize varieties (pop.66SR/ACR.91 SUWAH 1-SR and M2: pool18R/AK94DMRESR-Y). The sub-sub plot treatments comprised of three (3) sweet potato vine orientations (incline, loop and horizontal).

\section{Agronomic Practices}

Land preparation was done manually using hoes and cutlasses. Three maize seeds were sown at a spacing of $50 \mathrm{~cm}$ intra-row by the side of each ridge and thinned to two plant per stand ten (10) days after plant (40,000 plants/ha). Sweet potato vines of $30 \mathrm{~cm}$ in length were planted at the crest of each ridge at an intra-row spacing of $30 \mathrm{~cm}$ giving an approximate plant population density of 33,333 plants/ha. Both maize and sweet potato were planted on the same day. Intercropping had a 1:1(sweet potato: maize) row proportion. $200 \mathrm{~kg}$ of NPK 20:10:10 per ha was applied to maize in split doses by spot application while 400kg per ha of NKP 15:15:15 was applied to sweet potato. All plots were hand weeded at 3 and 7 weeks after planting (WAP).

The soil of experimental site was classified as Dysteric Ustopept (USDA). The same site was used for the experiment each year. Eight core sample soil were collected from different part of the experimental field from a depth of $0-30 \mathrm{~cm}$ and bulk into composite sample. The samples were air-dried at room temperature for one week, grind (using muster and pistle) to pass through air $0.3 \mathrm{~mm}$ screened for chemical and mechanical analysis (See Table Below)

\section{Data Collection}

All data at harvest were collected from the net plot. For the maize component, data was collected on plant height at 4, 8 and 12 WAP, cob length, number of kernels per cob, grain yield and hundred seed weight. Data on sweet potato component was collected on vine length, number of leaves per plant, number of branches per plant, root length, root diameter and weight of saleable roots. Saleable roots were fresh roots $\geq 150 \mathrm{~g}$.

\section{Assessment of Measures of Intercrop productivity}

Productivity of the various maize varieties intercropped with sweet potato in this work was determined by using land equivalent ratio (LER) as described by [14] and land equivalent coefficient (LEC) as illustrated by [15]. Competitive ratio (CR) which indicates the number of times by which one component crop is more competitive than the other was calculated using the formula proposed by [16].

\section{Data Analysis}

Standard procedures were followed in collecting all data and analysis was done using GENSTAT statistical software. Whenever differences between treatment means were significant, means were separated by Fishers Least Significant Difference at 5\% level of probability. T-test at 5\% probability was also used to separate treatment means where appropriate.

\section{Result}

\section{Sweet Potato Component Vine Length}

The main effect of cropping system, maize variety and vine orientation as well as the interaction effects of cropping system $x$ maize variety $x$ vine orientation was significant $(\mathrm{P} \leq 0.05)$ on the vine length of sweet potato at 4,8 and 12 WAP. 
At 4 WAP, sole sweet potato vines planted horizontally gave the highest vine length in both years and this was significantly higher than that produced by any other treatment. A similar trend was observed at 8 and 12 WAP where sole sweet potato planted horizontally gave the highest vine length in both years (Table 2). Regardless of the week and year evaluated, sweet potato vines which were looped and intercropped with pop.66SR/ACR.91 SUWAH 1-SR produced the lowest vine length (Table 2).

Physico-Chemical Properties of the
Sole cropping produced significantly higher vine length in both years and all the weeks evaluated than intercropping. Sweet potato intercropped with pool18R/AK94DMRESR-Y gave significantly higher vine length at 4,8 and 12 WAP than sweet potato intercropped with pop.66SR/ACR.91 SUWAH 1-SR in 2016 and 2017. Horizontally planted sweet potato gave significantly higher vine length than the other vine orientations at all the weeks evaluated and all the years examined (Table 1).

\section{Planting}

\begin{tabular}{|c|c|c|c|}
\hline & \multicolumn{2}{|c|}{ Values } & \\
\hline Soil Parameters & 2016 & 2017 & Method of Analysis \\
\hline Sand (\%) & 76.88 & 76.74 & Hydrometer Method \\
\hline Silt (\%) & 12.24 & 12.08 & Hydrometer Method \\
\hline Clay (\%) & 10.88 & 11.18 & Hydrometer Method \\
\hline Textural class & Sandy loam & Sandy loam & \\
\hline $\mathrm{pH}\left(\mathrm{H}_{2} \mathrm{O}\right)$ & 6.32 & 6.54 & PH meter \\
\hline Organic Carbon (\%) & 0.76 & 0.79 & Walky-Black \\
\hline Organic Matter (\%) & 0.48 & 0.46 & $\begin{array}{c}\text { Improved Chromic Acid } \\
\text { Digestive and }\end{array}$ \\
\hline Total Nitrogen (\%) & 0.64 & 0.76 & spectrophotometric method \\
\hline Available Phosphorus (ppm) & 4.86 & 4.88 & Kjeldah1 procedure \\
\hline $\mathrm{Cal}^{2+} \mathrm{Cmol} \mathrm{kg}^{-1}$ soil) & 2.46 & 2.48 & Bray-1 method \\
\hline $\mathrm{Mg}^{2+}\left(\mathrm{Cmol} \mathrm{kg}^{-1}\right.$ soil $)$ & 2.52 & 2.56 & AAS \\
\hline $\mathrm{K}^{+} \mathrm{Cmol} \mathrm{kg}^{-1}$ soil) & 0.36 & 0.34 & AAS \\
\hline $\mathrm{Na}^{+} \mathrm{Cmol} \mathrm{kg}^{-1}$ soil) & 0.25 & 0.28 & Flame phhotometer \\
\hline CEC Cmol kg-1 soil) & 7.68 & 6.84 & Flame phhotometer \\
\hline Base Saturation (\%) & 94.4 & 95 & Summation method \\
\hline
\end{tabular}


Table 1: Main Effect of Cropping System, Maize Variety and Sweetpotato Planting Position on the Vine Length of Sweet Potato in Makurdi in 2016 and 2017

\begin{tabular}{|c|c|c|c|c|c|c|}
\hline & \multicolumn{6}{|c|}{ Vine Length } \\
\hline & \multicolumn{2}{|c|}{4 WAP } & \multicolumn{2}{|c|}{8 WAP } & \multicolumn{2}{|c|}{12 WAP } \\
\hline Cropping System & 2016 & 2017 & 2016 & 2017 & 2016 & 2017 \\
\hline Intercrop Mean & 42.73 & 45.10 & 146.24 & 152.89 & 188.13 & 199.24 \\
\hline Sole & 52.59 & 54.76 & 163.44 & 167.35 & 212.00 & 222.73 \\
\hline LSD (0.05) & 3.54 & 3.98 & 5.32 & 6.94 & 9.43 & 11.42 \\
\hline \multicolumn{7}{|l|}{ Maize Variety } \\
\hline V1 & 42.58 & 44.58 & 137.96 & 144.24 & 183.38 & 196.49 \\
\hline V2 & 42.88 & 45.61 & 154.52 & 161.54 & 192.87 & 201.98 \\
\hline LSD (0.05) & 0.20 & 0.92 & 3.74 & 5.12 & 4.32 & 4.84 \\
\hline \multicolumn{7}{|l|}{ Vine Orientation } \\
\hline Horizontal & 48.47 & 51.25 & 163.40 & 168.79 & 206.53 & 220.59 \\
\hline Looped & 42.70 & 44.90 & 136.25 & 144.20 & 183.41 & 191.78 \\
\hline Inclined & 46.88 & 48.79 & 156.27 & 160.13 & 198.31 & 208.83 \\
\hline LSD (0.05) & 2.43 & 3.21 & 4.87 & 4.82 & 3.12 & 4.44 \\
\hline
\end{tabular}

Table 2: Growth Response of Sweet potato to Vine Planting Orientation in Intercropping and Sole cropping Systems in 2016 and 2017

\begin{tabular}{|c|c|c|c|c|c|c|}
\hline & \multicolumn{6}{|c|}{ Vine Length $(\mathrm{cm})$} \\
\hline \multirow{2}{*}{$\begin{array}{c}\text { Cropping } \\
\text { System }\end{array}$} & \multicolumn{2}{|c|}{4 WAP } & \multicolumn{2}{|c|}{8 WAP } & \multicolumn{2}{|c|}{12 WAP } \\
\hline & 2016 & 2017 & 2016 & 2017 & 2016 & 2017 \\
\hline $\begin{array}{l}\text { V1 + } \\
\text { Horizontal }\end{array}$ & 43.43 & 46.45 & 152.97 & 159.65 & 191.14 & 211.43 \\
\hline V1 + Looped & 41.19 & 42.65 & 118.15 & 124.53 & 174.38 & 184.51 \\
\hline V1 + Inclined & 43.11 & 44.64 & 142.9 & 148.5 & 184.63 & 193.53 \\
\hline Mean for V1 & 42.58 & 44.58 & 138.01 & 144.23 & 183.38 & 196.49 \\
\hline $\begin{array}{l}\text { V2 } \\
\text { Horizontal }\end{array}$ & 44.56 & 47.87 & 166.77 & 171.42 & 204.23 & 214.21 \\
\hline V2 + Looped & 40.43 & 43.53 & 140.43 & 153.76 & 184.25 & 190.43 \\
\hline V2 + Inclined & 43.65 & 45.42 & 156.37 & 159.43 & 190.21 & 201.13 \\
\hline Mean for V2 & 42.88 & 45.61 & 154.52 & 161.54 & 192.9 & 201.9233 \\
\hline $\begin{array}{l}\text { Sole } \\
\text { Horizontal }\end{array}$ & 44.43 & 49.43 & 170.47 & 175.31 & 224.64 & 236.52 \\
\hline Sole Looped & 40.47 & 41.53 & 150.33 & 154.32 & 191.6 & 200.35 \\
\hline Sole Inclined & 43.88 & 46.32 & 169.53 & 172.43 & 220.15 & 231.53 \\
\hline Mean for Sole & 42.93 & 45.76 & 163.44 & 167.35 & 212.13 & 222.8 \\
\hline LSD (0.05) & 1.25 & 1.01 & 0.56 & 0.8 & 1.06 & 1.2 \\
\hline Key: V1: po| & $\begin{array}{l}\mathrm{ACC} \\
\mathrm{Y} ;\end{array}$ & $1 \mathrm{SU}$ & 1_Cl & $2: \mathrm{p}$ & & RESR- \\
\hline
\end{tabular}




\section{Root Length}

The root length of sweet potato as influenced by the main effect of cropping system, maize variety and vine orientation as well as the interaction effects of cropping system $\mathrm{x}$ maize variety $\mathrm{x}$ vine orientation was significant $(\mathrm{P} \leq 0.05)$.

Data presented in Table 4 revealed that sole sweet potato planted horizontally gave the longest root length in 2016 $(24.25 \mathrm{~cm})$ and $2017(26.35 \mathrm{~cm})$ and this was significantly higher than that produced by any other treatment except inclined sole sweet potato $(23.68 \mathrm{~cm}$ and $24.56 \mathrm{~cm}$ respectively). The lowest root length of sweet potato in both years was produced when sweet potato was intercropped with pool18R/AK94DMRESR-Y and planted looped (Table 4).

In 2016 and 2017, sole cropping gave significantly higher root length $(23.07 \mathrm{~cm}$ and $24.52 \mathrm{~cm}$ respectively) of sweet potato than intercropping $(20.13 \mathrm{~cm}$ and $21.87 \mathrm{~cm}$

respectively). Sweet potato intercropped with pop.66SR/ACR.91 SUWAH 1-SR produced significantly higher root length in $2016(20.33 \mathrm{~cm})$ and $2017(22.10 \mathrm{~cm})$ than sweet potato intercropped with pool18R/AK94DMRESR-Y (19.92 and $21.64 \mathrm{~cm}$ respectively). Among the vine orientations evaluated, the horizontal position gave higher root length in $2016(22.07 \mathrm{~cm})$ and $2017(23.96 \mathrm{~cm})$ than the inclined $(21.44$ and $22.73 \mathrm{~cm}$ respectively) and looped (19.80 and $21.56 \mathrm{~cm}$ respectively) position respectively (Table 3).

\section{Root Diameter}

The main effect of cropping system and vine orientation as well as the interaction effects of cropping system $\mathrm{x}$ maize variety $\mathrm{x}$ vine orientation was significant $(\mathrm{P} \leq 0.05)$ on the root diameter of sweet potato in both years but the main effect of maize variety was not.

In 2016 sole sweet potato planted in horizontal position gave the highest root diameter $(7.12 \mathrm{~cm})$ but this was not significant different from that produced when sole sweet potato was planted in looped $(6.33 \mathrm{~cm})$ and inclined $(7.04 \mathrm{~cm})$ positions and when sweet potato was intercropped with pop.66SR/ACR.91 SUWAH 1-SR and planted in horizontal $(6.54 \mathrm{~cm})$ position (Table 4$)$. Similarly, sole sweet potato planted in horizontal position gave the highest root diameter $(8.21 \mathrm{~cm})$ in 2017 but this was only significantly higher than that produced when sweet potato was intercropped with pop.66SR/ACR.91 SUWAH 1-SR and planted in looped $(6.45 \mathrm{~cm})$ position and when sweet potato was intercropped with pool18R/AK94DMRESR-Y and planted in looped $(6.48 \mathrm{~cm})$ and inclined $(7.12 \mathrm{~cm})$ position (Table 4).

Sole cropping gave produced significantly higher root diameter than intercropping in 2016 (6.83 and $5.79 \mathrm{~cm}$ respectively) and $2017(8.06$ and $7.04 \mathrm{~cm}$ respectively). The horizontal position gave higher root diameter in $2016(6.53 \mathrm{~cm})$ and 2017 $(7.72 \mathrm{~cm})$ but this was only significantly higher than that produced by the looped (5.57 and $6.93 \mathrm{~cm}$ respectively) position (Table 3 )

\section{Number of Saleable Roots per Hectare}

The number of saleable roots per hectare as influenced by the main effect of cropping system, maize variety and vine orientation as well as the interaction effects of cropping system $\mathrm{x}$ maize variety $x$ vine orientation in 2016 and 2017 was significant $(\mathrm{P} \leq 0.05)$.

Data presented in Table 4 showed that sole sweet potato planted horizontally gave the highest number of saleable roots per hectare in 2016 (61453.64) and 2017 (62765.14) and the difference was significant.

Sole cropping gave significantly higher number of saleable roots per hectare in 2016 (57414.33) and 2017 (60768.57) than intercropping (54879.06 and 57500.90 respectively). Sweet potato intercropped with pop.66SR/ACR.91 SUWAH 1-SR gave significantly higher number of saleable roots per plant in 2016 (55410.44) and 2017 (57967.29) than sweet potato intercropped with pool18R/AK94DMRESR-Y (54347.67 and 57034.52 respectively). Among the vine orientations evaluated, the horizontal position gave significantly higher number of saleable roots per plant in 2016 (59117.83) and 2017 (60906.11) than all the other vine orientations (Table 3 ).

\section{Weight of Saleable Roots}

The main effect of cropping system and vine orientation as well as the interaction effects of cropping system $\mathrm{x}$ maize variety $\mathrm{x}$ vine orientation was significant $(\mathrm{P} \leq 0.05)$ on the weight of saleable roots of sweet potato in both years but the main effect of maize variety was not.

A cursory look at Table 4 revealed that sole sweet potato planted horizontally gave the highest weight of saleable roots in $2016(13.74 \mathrm{t} / \mathrm{ha})$ and 2017 (14.67t/ha) and this was significantly higher than that produced by all the other treatments except inclined sole sweet potato (13.13 and $14.33 \mathrm{t} /$ ha respectively). 
Sole cropping gave significantly higher weight of saleable roots in 2016 (12.99t/ha) and 2017 $(14.22 \mathrm{t} / \mathrm{ha})$ than intercropping (11.57 and $12.62 \mathrm{t} / \mathrm{ha}$ respectively). In both years, the horizontal position gave the highest weight of saleable roots but this was only significantly higher than that produced by the looped position (Table 3). 
Table 3: Main Effect of Cropping System, Maize Variety and Vine Orientation on the Yield and Yield Parameters of Sweet Potato in Makurdi in 2016 and 2017

\begin{tabular}{|c|c|c|c|c|c|c|c|c|}
\hline \multirow[b]{2}{*}{$\begin{array}{l}\text { Cropping } \\
\text { System }\end{array}$} & \multicolumn{2}{|c|}{$\begin{array}{l}\text { Root Length } \\
\text { (cm) }\end{array}$} & \multicolumn{2}{|c|}{$\begin{array}{c}\text { Root Diameter } \\
(\mathrm{cm})\end{array}$} & \multicolumn{2}{|c|}{$\begin{array}{c}\text { Number of } \\
\text { Saleable Roots per } \\
\text { Hectare }\end{array}$} & \multicolumn{2}{|c|}{$\begin{array}{c}\text { Weight of } \\
\text { Saleable Roots } \\
\text { (t/ha) }\end{array}$} \\
\hline & 2016 & 2017 & 2016 & 2017 & 2016 & 2017 & 2016 & 2017 \\
\hline Intercrop & 20.13 & 21.87 & 5.79 & 7.04 & 54879.06 & 57500.9 & 11.57 & 12.62 \\
\hline Sole & 23.07 & 24.52 & 6.83 & 8.06 & 57414.33 & 60768.57 & 12.99 & 14.22 \\
\hline LSD (0.05) & 1.23 & 2.31 & 0.67 & 0.74 & 153.76 & 169.32 & 0.87 & 1.32 \\
\hline \multicolumn{9}{|l|}{$\begin{array}{l}\text { Maize } \\
\text { Variety }\end{array}$} \\
\hline V1 & 20.33 & 22.1 & 5.89 & 7.07 & 55410.44 & 57967.29 & 11.55 & 12.5 \\
\hline V2 & 19.92 & 21.64 & 5.68 & 7.01 & 54347.67 & 57034.52 & 11.59 & 12.74 \\
\hline LSD (0.05) & 0.23 & 0.51 & NS & NS & 175.87 & 183.21 & NS & NS \\
\hline \multicolumn{9}{|l|}{$\begin{array}{l}\text { Vine } \\
\text { Orientation }\end{array}$} \\
\hline Horizontal & 22.07 & 23.96 & 6.53 & 7.72 & 59117.83 & 60906.11 & 12.83 & 13.84 \\
\hline Looped & 19.8 & 21.56 & 5.57 & 6.93 & 52316.61 & 55528.08 & 10.89 & 12.12 \\
\hline Inclined & 21.44 & 22.73 & 6.3 & 7.49 & 55738 & 59336.18 & 12.42 & 13.5 \\
\hline LSD (0.05) & 1.19 & 1.27 & 1.02 & 1.11 & 173.87 & 196.32 & 1.32 & 1.54 \\
\hline
\end{tabular}


Table 4: Yield and Yield Component of Sweet potato Response to Vine Planting Orientation in Intercropping and Sole cropping Systems in 2016 and 2017

\begin{tabular}{|c|c|c|c|c|c|c|c|c|}
\hline \multirow[t]{2}{*}{$\begin{array}{l}\text { Cropping } \\
\text { System }\end{array}$} & \multicolumn{2}{|c|}{$\begin{array}{l}\text { Root Length } \\
\text { (cm) }\end{array}$} & \multicolumn{2}{|c|}{$\begin{array}{l}\text { Root Diameter } \\
\text { (cm) }\end{array}$} & \multicolumn{2}{|c|}{$\begin{array}{l}\text { Number of Saleable } \\
\text { Roots per Hectare }\end{array}$} & \multicolumn{2}{|c|}{$\begin{array}{c}\text { Weight of } \\
\text { Saleable Roots } \\
\text { (t/ha) }\end{array}$} \\
\hline & 2016 & 2017 & 2016 & 2017 & 2016 & 2017 & 2016 & 2017 \\
\hline $\begin{array}{ll}\text { V1 } & + \\
\text { Horizontal }\end{array}$ & 18.23 & 19.3 & 7.2 & 7.65 & 59845 & 61462 & 11.75 & 12.25 \\
\hline V1 + Looped & 15.42 & 16.64 & 6.78 & 6.99 & 51560 & 53520 & 9.98 & 10.55 \\
\hline V1 + Inclined & 17.7 & 18.85 & 6.94 & 7.2 & 54650 & 58740 & 11.05 & 11.62 \\
\hline Mean for V1 & 17.12 & 18.26 & 6.97 & 7.28 & 55352 & 57907 & 10.93 & 11.47 \\
\hline $\begin{array}{ll}\text { V2 } & + \\
\text { Horizontal }\end{array}$ & 21.18 & 22.25 & 7.56 & 7.9 & 65920 & 66544 & 12.25 & 12.85 \\
\hline V2 + Looped & 16.83 & 19.5 & 6.91 & 7.15 & 59685 & 61350 & 10.65 & 11.45 \\
\hline V2 + Inclined & 18.42 & 21.8 & 7.1 & 7.56 & 63735 & 65045 & 11.88 & 12.15 \\
\hline Mean for V2 & 18.81 & 21.18 & 7.19 & 7.54 & 63113 & 64313 & 11.59 & 12.15 \\
\hline $\begin{array}{l}\text { Sole } \\
\text { Horizontal }\end{array}$ & 20.6 & 22.15 & 7.84 & 8.01 & 62588 & 64955 & 12.84 & 14.66 \\
\hline Sole Looped & 16.52 & 19.3 & 6.38 & 6.75 & 55250 & 58634 & 10.99 & 11.45 \\
\hline Sole Inclined & 18.31 & 20.4 & 7.15 & 7.5 & 58754 & 61250 & 11.79 & 12.7 \\
\hline Mean for Sole & 18.48 & 20.62 & 7.12 & 7.42 & 58864 & 61613 & 11.87 & 12.94 \\
\hline LSD (0.05) & 1.25 & 1.01 & 0.56 & 0.8 & 145.52 & 162.4 & 1.06 & 1.2 \\
\hline
\end{tabular}




\section{Maize Component \\ Cob Length}

Vine orientation and intercropping had significant $(\mathrm{P} \leq 0.05)$ effect on the cob length of maize in Makurdi in 2016 and 2017.

Data presented in Table 5 showed that pool18R/AK94DMRESR-Y intercropped with horizontally planted sweet potato produced the highest cob length of maize in $2016(30.30 \mathrm{~cm})$ and $2017(30.87 \mathrm{~cm})$ and the difference was significantly higher than that produced by any other treatment except sole pool18R/AK94DMRESR-Y (28.77 and $30.72 \mathrm{~cm}$ respectively).

\section{Number of Seeds per Cob}

The number of seeds per cob as influenced by vine orientation and cropping system was significant $(\mathrm{P} \leq 0.05)$ in 2016 and 2017.

In 2016, pool18R/AK94DMRESR-Y intercropped with horizontally planted sweet potato gave the highest number of seeds per cob (543.29) and this was significantly higher than that produced by any other treatment. A dissimilar trend was observed in 2017 where sole pool18R/AK94DMRESR-Y gave the highest number of seeds per cob (532.67) and the difference was significantly higher than that produced by all the other treatments except pool18R/AK94DMRESR-Y intercropped with sweet potato planted inclined (518.15) and sole pop.66SR/ACR.91 SUWAH 1-SR (524.46) (Table 5).

\section{Cob Weight}

Vine orientation and intercropping had significant $(\mathrm{P} \leq 0.05)$ effect on the cob weight of maize in Makurdi in 2016 and 2017.

Data presented in Table 5 showed that sole pool18R/AK94DMRESR-Y produced the highest cob weight in 2016 (7.89t/ha) and 2017 (8.21t/ha) among the treatments evaluated. pop.66SR/ACR.91 SUWAH 1-SR intercropped with looped sweet potato gave the lowest cob weight in 2016 (5.06t/ha) and 2017 (5.32t/ha) (Table 5).

\section{Grain Yield}

Vine orientation and intercropping had significant $(\mathrm{P} \leq 0.05)$ effect on the grain yield of maize in Makurdi in 2016 and 2017.

Sole pool18R/AK94DMRESR-Y produced the highest grain yield of maize in $2016(1.51 \mathrm{t} / \mathrm{ha})$ and 2017 (2.98t/ha) and the difference was significantly higher than that produced by any other treatment. The lowest grain yield was produced when pop.66SR/ACR.91 SUWAH 1-SR was intercropped with looped sweet potato in 2016 (0.88t/ha) and 2017 (2.03t/ha) (Table 5).

\section{0-Seed Weight}

The 100-seed weight of maize as influenced by vine orientation and cropping system was significant $(\mathrm{P} \leq 0.05)$ in 2016 and 2017.

In 2016, sole pool18R/AK94DMRESR-Y produced the highest 100-seed weight $(24.50 \mathrm{~g})$ and the difference was significant. A similar trend was observed in 2017 where sole pool18R/AK94DMRESR-Y also produced the highest 100 -seed weight $(25.87 \mathrm{~g})$ and the difference was significantly higher than that produced by all the other treatments except sole pop.66SR/ACR.91 SUWAH 1-SR (Table 5).

Assessment of Measures of Intercrop Productivity

Table 6 presents the results of measures of intercrop productivity [Land Equivalent Ratio (LER), Land Equivalent Coefficient (LEC)] and measures of competitive interactions [Competitive Ratio (CR)] between the intercrop components of maize and sweet potato in Makurdi in 2016 and 2017.

All intercrop combinations had LER figures above 1.0 and LEC values above 0.25 in both years. CR values of sweet potato were consistently higher than those of maize in all intercrop combinations in 2016 and 2017. 
Table 5: Effect of Vine Orientation and Intercropping on some Yield Components of Maize in Makurdi in 2016 and 2017

\begin{tabular}{|c|c|c|c|c|c|c|c|c|c|c|}
\hline \multirow[t]{2}{*}{ Treatment } & \multicolumn{2}{|c|}{$\begin{array}{l}\text { Cob Length } \\
\text { (cm) }\end{array}$} & \multicolumn{2}{|c|}{$\begin{array}{c}\text { Number of } \\
\text { Seeds per Cob }\end{array}$} & \multicolumn{2}{|c|}{$\begin{array}{c}\text { Cob Weight } \\
\text { (t/ha) }\end{array}$} & \multicolumn{2}{|c|}{$\begin{array}{c}\text { Grain Yield } \\
\text { (t/ha) }\end{array}$} & \multicolumn{2}{|c|}{$\begin{array}{l}\text { 100-Seed } \\
\text { Weight (g) }\end{array}$} \\
\hline & 2016 & 2017 & 2016 & 2017 & 2016 & 2017 & 2016 & 2017 & 2016 & 2017 \\
\hline V1 + Horizontal SP & 22.10 & 23.43 & 455.12 & 467.70 & 5.59 & 5.94 & 1.03 & 2.33 & 22.00 & 23.43 \\
\hline V1 + Looped SP & 20.67 & 21.32 & 439.67 & 456.36 & 5.06 & 5.32 & 0.88 & 2.03 & 21.60 & 23.12 \\
\hline V1+ Inclined SP & 21.00 & 22.98 & 494.34 & 503.43 & 5.88 & 6.01 & 1.09 & 2.48 & 22.30 & 23.87 \\
\hline Mean for V1 & 21.26 & 22.58 & 463.04 & 475.83 & 5.51 & 5.76 & 1.00 & 2.28 & 21.97 & 23.47 \\
\hline V2 + Horizontal SP & 30.30 & 30.87 & 543.29 & 515.09 & 6.32 & 6.87 & 1.12 & 2.39 & 22.67 & 24.05 \\
\hline V2 + Looped SP & 23.40 & 24.66 & 462.34 & 484.34 & 5.74 & 6.04 & 0.91 & 2.11 & 22.07 & 23.64 \\
\hline V2+ Inclined SP & 27.23 & 27.86 & 511.34 & 518.15 & 6.80 & 7.32 & 1.24 & 2.53 & 22.73 & 24.54 \\
\hline Mean for V2 & 26.98 & 27.80 & 505.66 & 505.86 & 6.29 & 6.74 & 1.09 & 2.34 & 22.49 & 24.08 \\
\hline Mean for Intercropping & 24.12 & 25.19 & 484.35 & 490.85 & 5.90 & 6.25 & 1.05 & 2.31 & 22.23 & 23.78 \\
\hline Sole V1 & 22.37 & 24.54 & 514.60 & 524.46 & 7.68 & 7.92 & 1.34 & 2.43 & 23.27 & 25.32 \\
\hline Sole V2 & 28.77 & 30.72 & 521.62 & 532.67 & 7.89 & 8.21 & 1.51 & 2.98 & 24.50 & 25.87 \\
\hline Mean for Sole Cropping & 25.57 & 27.63 & 518.11 & 528.57 & 7.79 & 8.07 & 1.43 & 2.71 & 23.89 & 25.60 \\
\hline LSD (0.05) & 2.16 & 3.32 & 19.14 & 15.32 & 1.74 & 1.23 & 0.19 & 0.23 & 0.43 & 0.67 \\
\hline
\end{tabular}

Table 6: Land Equivalent Ratio (LER), Land Equivalent Coefficient (LEC) and Competitive Ratio (CR) of Intercropped Maize with Sweet Potato in Makurdi in 2016 and 2017.

\begin{tabular}{|l|c|c|c|c|c|c|c|c|c|}
\hline \multirow{2}{*}{ Treatment } & \multicolumn{2}{|c|}{ LER } & \multicolumn{2}{|c|}{ LEC } & \multicolumn{2}{c|}{ CR-Maize } & \multicolumn{2}{c|}{ CR-Sweet Potato } \\
\cline { 2 - 10 } & $\mathbf{2 0 1 6}$ & $\mathbf{2 0 1 7}$ & $\mathbf{2 0 1 6}$ & $\mathbf{2 0 1 7}$ & $\mathbf{2 0 1 6}$ & $\mathbf{2 0 1 7}$ & $\mathbf{2 0 1 6}$ & $\mathbf{2 0 1 7}$ \\
\hline V1 + Horizontal SP & 1.83 & 1.88 & 0.62 & 0.88 & 0.75 & 0.96 & 1.34 & 1.04 \\
\hline V1 + Looped SP & 1.70 & 1.67 & 0.50 & 0.70 & 0.68 & 1.00 & 1.48 & 1.00 \\
\hline V1 + Inclined SP & 1.76 & 1.89 & 0.64 & 0.89 & 0.81 & 0.86 & 1.23 & 1.17 \\
\hline V2 + Horizontal SP & 1.80 & 1.71 & 0.74 & 0.73 & 0.94 & 0.88 & 1.06 & 1.13 \\
\hline V2 + Looped SP & 1.66 & 1.53 & 0.57 & 0.58 & 0.81 & 0.86 & 1.23 & 1.16 \\
\hline V2 + Inclined SP & 1.90 & 1.80 & 0.88 & 0.81 & 0.98 & 0.89 & 1.02 & 1.12 \\
\hline LSD (0.05) & 0.23 & 0.12 & 0.15 & 0.21 & 0.11 & 0.20 & 0.15 & 0.63 \\
\hline
\end{tabular}




\section{Discussion \\ Sweet Potato Component}

The vine length of sweet potato increased steadily from 4 to 12 WAP and was significantly affected by cropping system, intercropping with maize variety and vine orientation. Similarly all yield and yield parameters of sweet potato evaluated were significantly affected by cropping system, maize variety and vine orientation. Sole cropping gave significantly higher growth and yield parameters sweet potato at all the weeks evaluated in both years than intercropping. The reductions observed in the vine length, root diameter, root length, number of saleable roots per hectare and weight of saleable roots of sweet potato intercropped with maize varieties might be due to inter-specific competition from the taller maize component for both above- and below- ground growth resources (light, air, water, nutrients). This result agrees with the findings of [17]. The higher growth and yield parameters produced when sweet potato was intercropped with pop.66SR/ACR.91 SUWAH 1-SR over when it was intercropped with pool18R/AK94DMRESRY suggest that pop.66SR/ACR.91 SUWAH 1-SR was more compatible for intercropping with sweet potato than pool18R/AK94DMRESR-Y.

Horizontal planting produced higher vine length, root diameter, root length, number of saleable roots per hectare and weight of saleable roots than all the other vine orientations in both years. The present findings are in close agreement with those of [18]. This may be attributed to the numerous sprouting points created by this method of planting which satisfied the necessary conditions for growth and tuber formation. The differences in spatial arrangement of the vine cuttings at planting may also be responsible for the better performance of the horizontal planting position over the other orientations. [19] stated that in horizontal vine orientation, the subterranean nodes are more spaced apart than those in the loop vine orientation and incline vine orientation in this study. Formation of a loop design, automatically place subterranean nodes closer to each other. A similar behavior is also experienced in the incline vine orientation. This may increase competition and therefore affect the water and nutrient uptake of the subterranean nodes in the other vine orientations than in the horizontal vine orientation. [20] also made a similar observation in their study and reported that the subterranean nodes in horizontal vine orientation had more space to draw up nutrients and water which facilitated photosynthesis and production of photoassimilates [11].

\section{Maize Component}

Results obtained from the study showed that sole cropping gave higher cob length, number of seeds per cob, cob weight, grain yield and 100-seed weight than intercropping. [21] made a similar observation when most of the maize varieties evaluated showed degree of yield decrease under cassava-maize intercropping system compared to sole maize. The decrease in intercropping might be due to inter-specific competition between maize and sweet potato for below and above ground growth factors i.e. soil moisture, nutrient, space and solar radiation. [22] explained that sharing of growth resources among components crops under intercropping can limit growth and accumulation of dry matter compared to sole cropping where competition exists. [23] also made a similar observation when they intercropped maize with mung-beans.

Significant varietal effects were observed on yield and yield parameters of maize. The variation in cob length, number of seeds per cob, cob weight, grain yield and 100-seed weight were expected as genetic composition of these varieties were probably different. [24] also had observed wide variation among maize varieties in most of the parameters studied and attributed such differences to genetic composition.

\section{Intercrop Productivity}

The indices (LER, and LEC) used to evaluate intercrop productivity in this study indicated intercrop advantages in both years, implying that land would be saved by adopting intercropping rather than sole cropping of either maize or cowpea. [25] had reported that row intercropping of cocoyam with upland rice in Umudike and Otobi enhanced the total yield of mixture components through complimentary yield advantages, resulting in high productivity efficiency. Competitive ratio (CR) could be useful in comparing the competitive ability of the different crops and it may help clarify the nature of competition between component crops [26]. Sweet potato was the more dominant component of the maize/sweet potato intercropping systems, probably because of its deep roots advantage.

\section{Conclusion}

Sole cropping gave higher cob length, number of seeds per cob, cob weight, grain yield and 100- 
seed weight of maize than intercropping in both years. In both years, pool18R/AK94DMRESR-Y produced higher values for the maize parameters evaluated than pop.66SR/ACR.91 SUWAH 1-SR irrespective of the cropping system.

In 2016 and 2017, horizontal planting produced higher vine length, root diameter, root length, number of saleable roots per hectare and weight of saleable roots than all the other vine orientations. Intercropping with pop.66SR/ACR.91 SUWAH 1SR gave higher growth and yield parameters than intercropping with pool18R/AK94DMRESR-Y. All intercrop combinations had LER figures above 1.0 and LEC values above 0.25 in both years. CR values of sweet potato were consistently higher than those of maize in all intercrop combinations in 2016 and 2017.

\section{References}

[1] Oluwaranti, A., Fakorede, A. Menkir, M.A.B., Akinyooye1, A., and Bello, A.O. (2015). Evaluation of late maturing maize varieties for late season planting in a rainforest location of Nigeria. International Journal of Agronomy and Agricultural Research. 7(4):111-116

[2] Afzal, M., Nasir, Z., Bashir, M.H. and Khan, B.S. (2009). Analysis of List Plant resistance in some genotypes of maize against ChiloPartellus (Swinhoe) (Pyralidae: Lepidoptera). Pakistan J. Botany. 41:421-428.

[3] Iken, J. E., Anusa, A. and Obaloju, V. O. (2001). Nutrient Composition and Weight Evaluation of some Newly Developed maize Varieties in Nigeria. Journal of Food Technology, 7: 25-28.

[4] Raemaekers, R. H. (2001). Crop Production in Tropical Africa, CIP Royal Library Albert 1, Brussel.

[5] Cuminging, J.H., Beatty, E.R. and Englyst, H.N. (2009). Physiological properties of improved sweet potato varieties. $\mathrm{J}$. Nutrition, 75: 733-737.

[6] Woolfe, J. A. (1992). Sweet potato: An untapped food resource, Cambridge University Press and International Potato

[7] Antia, B.S., Akpan, E.J. Okon, P.A. and Umoren, I.U. (2006). Nutritive and antinutritive evaluation of sweet potato leaves J. Nutr., 5: 166-168.

[8] Ossom, E.M. 2010. Influence of sweet potato/ maize association on ecological properties and crop yields in Swaziland. International Journal of Agriculture and Biology 12: 481- 488

[9] Udealor A., Ezulike, T.O., Nwauzor, E.C., Asumugha, G.N. and Amaefula A. 2006. Evaluation of different sweet potato varieties under different intercropping systems. Annual Report of the National Root Crops Research Institute (NRCRI), Umudike, Nigeria. pp.

[10] Onwuene, I.C. (1999). The Tropical Tuber Crops, John Wiley and Sons Ltd, London, p. 43.

[11] Chagonda, I., Mapfeka, R.F. and Chitata, T. (2014) Effects of Tillage Systems and Vine Orientation on Yield of Sweet potato (Ipomoea batas L.). American Journal of Plant Sciences. Volume 5. pp 3159-3165.

[12] Dhliwayo, P., Chiunzi, P.D. (2004). A Guide to profitable sweet potato production, Harare, Biotechnology Trust of Zimbabwe, pp. 3-9.

[13] Kowal, J.M., and Knabe, D.T. (1972); An agro-climatological atlas of Northern States of Nigeria, Ahmadu Bello University Press, Zaria.

[14] Ofori, F. and Stern, W.R. (1987a) Cereallegume intercropping systems. Advances in Agronomy, 41: 41-49.

[15] Adetiloye, P.O., F.O.C. Ezedinma and B.N. Okigbo, 1983. A land Equivalent Coefficient (LEC) concept for the evaluation of conmpetitive and productive interactions in simple to complex crop mixtures. Ecol. Modelling, 191: 27-39.

[16] Willey, R.W. and M.R. Rao, 1980. A competitive ratio for quantifying competition between intercrops. Exp. Agric., 16: 117-125.

[17] Egbe, O.M. and Idoko.J.A. 2009. Agronomic assessment of some sweet potato varieties for intercropping with pigeonpea in Southern Guinea Savanna of Nigeria. ARPN Journal of Agricultural and Biological Science, 4(4):23-32

[18] Parwada C, Gadzirayi T, Sithole AB (2011). Effect of ridge height and planting orientation on Ipomeabatatas(sweet potato) production; J. Agric. Biotechnol. Sustainable Dev., 3(4): 72- 76.226- 228.

[19] Chagonda, I., Mapfeka, R.F. and Chitata, T. (2014) Effects of Tillage Systems and Vine Orientation on Yield of Sweet potato 
(Ipomoea batas L.). American Journal of Plant Sciences. Volume 5. pp 3159-3165.

[20] Lewthwaite, S.L. and Triggs, C.M. (2009). Identification of paraquat-resistant Solanumnigrum and

S.americanumbiotypes. New Zealand Plant Protection62, 349-55

[21] Adeniyan, O.N., A.O. Ojo, O.A. Akinbode and J.A. Adediran, 2011. Comparative study of different organic manures and NPK fertilizer for improvement of soil chemical properties and dry matter yield of maize in two different soils. J. Soil Sci. Environ. Manage, 2: 9-13.

[22] Dasbak, M.A.D., Asiegbu, J.E., (2009). Performance of pigeon pea genotypes intercropped with maize under humid tropical ultisol conditions. Journal of Animal and Plant Sciences 4 (2): $\quad 329$ 340.

[23] Muhammad, A.K., Khalid, N., Kawsar, A., Bashir, A. and Samin, J. (2012). Impact of Mungbean- Maize Intercropping on growth and Yield of Mungbean. Pak. J. Weed Sci. Res. 18(2): 191- 200,
[24] Akaazua, B.W., Adzer, Y. and Owoyemi, S.S. (2017). Performance of Introduced Maize Varieties in Makurdi, Southern Guinea Savanna of Nigeria. Proceedings of the $41^{\text {st }}$ Annual Conference of the Genetics Society of Nigeria, University of Agriculture, Makurdi, $\quad$ Nigeria. pp 126-128.

[25] [Okwuowulu, P. A., Asiegbu, J. E., and Nnado, W. F. (2002). Effect of row intercropping of cocoyam minisett on tuber/GARI yield and productivity in south eastern Nigeria. Journal of Sustainable Agricultural and Environment, 2, 214-225

[26] Egbe, O.M., (2005). Evaluation of some agronomic potential of pigeonpea genotypes for intercropping with maize and sorghum in Southern Guinea Savanna.Ph.D. Thesis, University of Agriculture, Makurdi, Nigeria 